\title{
Frejdigt Mod i Jesu Navn!
}

\author{
Konstruktionen af danske helte i 1864
}

\author{
Ph.d.-stipendiat, cand. theol. \\ Michael Perlt
}

\begin{abstract}
Collective self-understanding, in which the making of history and narratives is crucial, is not unproblematic. A shared history and myths belonging to a certain group and a historical territory, are vital ingredients in the construction and forging of narratives and collective identity. This paper aims to trail the interplay between social performance and the construction of narratives in times of crisis. The combination of memory, performance, and crisis is exemplified through a sermon held by Ludvig Helveg in Odense on Palm Sunday 1864 at the time of the 2nd War of Schleswig-Holstein. As the French psychiatrist Pierre Janet has said: "Memory is an action, essentially, it is the action of telling and staging a story". The staging of social performances serves to secure and strengthen a collective consciousness in the interplay between the interpretation of the past, understanding of the present, and expectations of the future.
\end{abstract}

Keywords: Narrative - collective identity - social performance - collective memory and trauma - conflict - Denmark 1864.

Formålet med denne artikel er at undersøge brugen af kollektiv erindring i krisetider og sociale aktørers opbygning af fælles identitet. For at belyse en dynamisk brug af en fælles national, religiøs, og kulturel baggrund tager undersøgelsen udgangspunkt i de historiske begivenheder i Danmark omkring Palmesøndag den 20. marts 1864. I undersøgelsen vil der blive arbejdet med præsten og historikeren Ludvig Helvegs (1818-1883) prædiken Frejdigt Mod i Jesu Navn! holdt i Odense Palmesøndag 1864 og senere udkommet som tryk samme år. Prædikenen er søgt analyseret som et socialt performativ for at påvise den aktive og levende dialog mellem fortid, nutid og fremtid, som Helveg og andre af de grundtvigiansk inspirerede præster og historikere havde. Ved at analysere Helvegs prædiken i performative vendinger, tilstræber artiklen at vise, hvordan Helveg gennem sin 
prædiken til menigheden/læseren søgte at skabe et fælles narrativ for de traumatiske begivenheder omkring marts $1864 .{ }^{1}$

For at overvinde kløften mellem en fortidig traumatisk oplevelse og nuet, mellem begivenheden og dens repræsentation, kræves en overbevisende bearbejdelse og strukturering af en begivenhed i forhold til en gruppes fælles erindring. Som den franske psykiater Pierre Janet (1859-1947) siger om traumatiske erindringer i Les Médicationes Psychologies (1919), det er på den ene side "bare" at fortælle en ny historie. ${ }^{2} \mathrm{Og}$ på den anden side er det at konstruere et narrativ om en traumatisk begivenhed en kompleks symbolsk proces, der ofte sætter skel, og hvis gyldighed kan bestrides. At berette og konstruere en fælles fortælling om en begivenhed kræver derfor kulturelle aktører, der er begavet med egenskaberne og magten til at sætte en fælles dagsorden. Aktørernes præsentation af begivenheden - narrativet om den traumatiske begivenhed, krisen eller konflikten, kan anskues som "fordringer" på et virkelighedsbillede. ${ }^{3}$

Et eksempel er forfatteren Hans Peter Holsts (1811-1893) sammenligning af den danske hærs forsvar af hertugdømmerne Slesvig og Holsten i 1864 med spartanernes forsvar af bjergpasset ved Thermopylæ i 480 f.Kr. Dette billede på den danske kamp blev fremført allerede i månederne efter den danske hærs nederlag i den 2. Slesvigske Krig. ${ }^{4}$

Jo, det skal vidnes og sandes af alle:

Danmark har Børn af Spartanernes Slægt.

Dybbøl, som værgedes mandigt og kjækt,

Tør vi Thermopylæ kalde

Ei må Du tvivle mit fædreland!

(Adriansen 2003, 253).

1. Sociologen og forfatteren Erving Goffman (1922-1982) fremhæver i sin for forskningsfeltet betydningsfulde bog The Presentation of Self in Everyday Life (Garden City, New York: Doubleday \& Co. 1959) forbindelsen mellem det sociale liv og det performative. Selve vendingen mod en brug af konceptet performance er kommet fra en bred vifte af akademiske discipliner, såsom sociologi (Pierre Bourdieu), antropologi (Victor Turner og Clifford Geertz), sprogfilosofi (J.L. Austin, Kenneth Burke, John Searle) osv.

2. Pierre Janet, Les Médicationes Psychologies, 3 vols. (Paris: Sociéte Pierre Janet 1919), 84; van der Kolk \& van der Hart, "The Intrusive Past: The Flexibility of Memory and the Engraving of Trauma", Trauma - Explorations in Memory, red. Cathy Caruth (London: John Hopkins University Press 1995), 158-182 (175).

3. Jeffrey C. Alexander, "Toward a Theory of Cultural Trauma", Cultural Trauma and Collective Identity, red. Alexander, Eyerman, m.fl. (Berkeley, CA: University of California Press 2004), 1-30 (11).

4. Inge Adriansen, Nationale Symboler i Det Danske Rige 1830-2000, (København: Museum Tusculanums Forlag Københavns Universitet 2003) 253 - NB! Ortografien vil i alle citater $\mathrm{i}$ artiklen blive bibeholdt. 
Sammenligningen med kong Leonidas og hans 300 krigere, der tappert havde kæmpet mod en overlegen fjende for at forsinke den persiske hær der invaderede hjemlandet, forekom som en indlysende tolkning af begivenhederne omkring den tyske invasion og tabet af hertugdømmerne. Digtet om de danske spartanere rummer selvfølgelig en stærk forenkling og en heroisme, der ingen dækning er for $\mathrm{i}$ begivenhederne omkring 1864. De heroiserede narrativer om den 2 . Slesvigske Krig har således generelt medvirket til at sløre forståelsen af, hvad der reelt skete med den danske nation og den fælles identitet som danskere efter krigen.

Sange, prædikener, digte, monumenter og skulpturer, produkter af kulturelle aktører har været med til at fastholde en helteglans over tragedien og sløret traumet omkring krigen og tabet af hertugdømmerne. Sociologen Neill J. Smelser har i sin artikel "Psychological Trauma and Cultural Trauma" fra 2004 søgt at give en formel definition på et kollektivt traume. Smelser taler således om det kollektive traume som: en accepteret og offentligt anerkendt erindring, der er givet troværdighed af en relevant gruppe om en handling og situation der i sin pludselighed (a) er ladet med en negativ effekt, (b) fremstillet som uudslettelig og (c) anset som truende for et samfunds, kollektivs eller gruppes eksistens eller krænkende for en eller flere af dets fundamentale forudsætninger for at opretholde en fælles identitet. ${ }^{6}$ Nederlaget i 1864 kan om noget defineres som et bittert slag for nationen, et knæk for den fælles danske identitet, da landet som følge af krigen både befolknings- og ressourcemæssigt var blevet formindsket med næsten $40 \%$. Danmarks tid som stormagt var definitivt ovre. ${ }^{7}$

Men hvad ledte til denne nationale tragedie? Efter Revolutions- og Napoleonskrigene (1792-1815) blomstrede der i Europa en national bevidsthed og national følelse, der i Tyskland i 1815 mundede ud i dannelsen af et forbund mellem 39 tyske enkeltstater (hertugdømmer, grevskaber, fristæder osv.). Blandt disse var også grevskabet Holsten, repræsenteret af den danske konge. ${ }^{8} \mathrm{Da}$ Holsten derfor både var en del af den danske helstat og medlem af det tyske forbund, lå

5. Neill J. Smelser, "Psychological Trauma and Cultural Trauma", Cultural Trauma and Collective Identity red. Alexander, Eyerman, m.fl . (Berkeley, CA: University of California Press 2004), 31-59.

6. I hvilken udstrækning man kan tale om fælles nationale traumer kan er og blevet diskuteret eksemplevis af Wulf Kantsteiner og Harald Weilnbock i deres artikel "Against the Concept of Cultural Trauma", Cultural Memory Studies. An International and Interdisciplinary Handbook, red. Astrid Erll \& Ansgar Nünning (Berlin: De Gruyter 2008), 229-240.

7. Ole L. Frantzen, Danmarks Krigshistorie 1814-1870 bd. II, red. Frantzen \& Jespersen (København: Gads Forlag 2008), 134-147 (134).

8. Inge Adriansen, 1864 i samtidens aviser (København: Gyldendal 1976), 9-13. 
der heri en kilde til spændinger mellem danske og tyske interesser. I 1830 'erne rejstes der i flere af de europæiske lande krav om frie forfatninger og i adskillige områder i Europa spirede liberale tanker frem. ${ }^{9}$ Også i hertugdømmerne Slesvig og Holsten stod de liberale tanker i kontrast til det oldenborgske kongehus på Danmarks trone. I det store revolutionsår 1848 løb modstridende tanker, begivenheder og tilfældigheder sammen i det danske rige. ${ }^{10}$ Den 29. februar 1848, kun få dage efter revolutionen i Paris (21-24. februar), blev Christian den 8. (1786-1848) begravet i Roskilde Domkirke, og liberale, nationale og arvefølgepolitiske spørgsmål udviklede sig til en åben konflikt, som førte til prinsen af Nørs overtagelse af fæstningen Rendsborg og en efterfølgende borgerkrig mellem de preussisk støttede slesvigholstenere og den danske hær. ${ }^{11}$ Efter den danske hærs sejr ved slaget på Isted Hede kunne Danmark generobre hele Slesvig i 1850.

Den 15. november 1863, tretten år efter den 1 . Slesvigske Krig døde den ellers så folkekære Kong Frederik den 7. Han tituleredes konge af Guds nåde, de Venders og Gothers, Hertug til Slesvig, Holsten, Stormarn, Ditmarsken, Lauenborg og Oldenborg og var den sidste konge af den oldenborgske slægt. $\mathrm{Nu}$ døde han uden arving til det danske rige. ${ }^{12}$ Siden krigen (1848-1850) havde man ikke fundet en passende ordning på hertugdømmernes forhold til den danske stat og på trods af aftaler indgået i 1852 vedtog den danske regering i København alligevel en fælles forfatning for kongeriget, Slesvig og Holsten/Lauenborg (Helstatsforfatningen af 1855). Den tyske offentlighed og de tyske politikere ønskede derimod en tysk enhedsstat - et ønske støttet af Otto von Bismarck (1815-1898), der var blevet Preussens kansler i 1862. Han hindrede derfor reeelle forhandlinger mellem den danske regering og det tyske forbund om det danske brud på aftalen fra 1852 (Adriansen 1976, 10). Den 31. januar 1864 henvendte ledende preussiske officerer sig til den danske general De Meza (1792-1865). De $ø$ nskede, at den danske hær skulle rømme dens stillinger ved Dannevirke. Det nægtede general De Meza og den 1. februar 1864 var den 2. Slesvigske Krig derfor en realitet.

De Meza rømmede alligevel Dannevirke den 5. februar for at redde den danske hær fra at blive løbet over ende. Via aviserne fik den danske befolkning hurtigt besked om krigsbegivenhederne. Meddelelsen

9. Axel Johnsen, 1848-1850 Med Gud! For Konge og Fødeland! Für Freiheit und Einheit! (Sønderborg: Sønderjyllands Amt 1998), 11-12.

10. Februarrevolutionen i Frankrig, Martsrevolution i Tyskland, Den Ungarske Revolution, alle i 1848 .

11. 1. Slesvigske Krig, også kaldet Treårskrigen 1848-50.

12. Kristian Hvidt, "Det Folkelige Gennembrud og dets Mænd", Gyldendal og Politikens Danmarkshistorie bd. 11, red. Olaf Olsen (København: Forlagene Gyldendal \& Politiken 1993), 122. 
om rømningen af Dannevirkestillingen ramte befolkningen hårdt, først og fremmest fordi der ikke var overensstemmelse mellem stillingens faktiske styrke og så de forestillinger herom, som florerede i befolkningen. I tiden op til krigen havde stillingen stået som et symbolsk bolværk mod tyskerne i det danske folks bevidsthed (Frantzen 2008 124). Om reaktionen på hærens tilbagetrækning fra Dannevirke skriver Fr. Hammerich i sine erindringer fra 1882:13

Da fór det som en løbeild gennem landet: Danevirke er rømmet den 5 te februar i mulm og nat! Hele København kom i voldsomt røre, man råbte højt på forræderi, mængden var næppe til at styre, og hvo kan undres derover? Næste dag var en søndag, Grundtvig stod for altret med strømmende tårer, prædike kunde han ikke, men indbød enhver, der ønskede det, til det eneste sted, hvor trøst var at finde, Herrens bord (Hammerich 1882, 195).

Danevirkes rømning skete uden regeringens vilje og vidende, den udsåede bitter mistro overalt, og den var en svær synd mod det danske folk; dets modstandskraft, hidtil usvækket, var brudt i samme øjeblik, den skuldes prøves (Hammerich 1882, 196).

\section{Narrativer og truet identitet}

Som Smelser definerer det, kan der ved en traumatisk begivenhed dannes skår i den fælles identitet. Den fælles identitet er så at sige individets sociale sikkerhedsnet, den kontekst hvori der søges trøst og hvor bindende og vedvarende traditioner opstår. Ved en krise i den fælles identitet skabes der et behov for, at kulturelle aktører gennem sociale performativer konstruerer en "ny" fortælling om gruppen der kan reetablere de tryghedsskabende traditioner og fortællinger. Denne nye fortælling inkluderer en genfortolkning af den traumatiske begivenhed som en fortid, der kan forliges med nutiden og fremtiden. ${ }^{14}$ Det sociale performativ kan ses som den lejlighed, i hvilken en kultur, et samfund eller en gruppe reflekterer over og definerer sig selv igennem en dramatisering af de fælles myter og historier, der fremlægger alternativer og fordrer ændringer. ${ }^{15}$ Det sociale perfor-

13. Fr. Hammerich, Et Levnetsløb, red. Angul Hammerich (København: Forlagsbureauet 1882).

14. Ron Eyerman, "The Past in the Present: Culture and Transmission of Memory", Acta Sociologica, 47:2 (2004), 159-169.

15. Jeffrey C. Alexander \& Jason L. Mast, "Introduction: symbolic action in theory and practice: the cultural pragmatics of symbolic action", Social Performance: Cultural Pragmatics and Ritual, red. J.C. Alexander, B. Giesen \& J.L. Mast (Cambridge: Cambridge University Press 2006), 1-28 (13). 
mativ kan også anskues som en dynamisk proces, i hvilke kulturelle aktører enten individuelt eller i fælleskab udfolder betydningen af den givne traumatiske begivenhed. Betydningen af det sociale performativ kan være, men er ikke nødvendigvis, delt af aktøren. Det afgørende er selve tydningen af en begivenhed, som aktøren bevidst eller ubevidst ønsker at viderebringe og overbevise sit publikum om. For at den kulturelle aktørs udfoldelser kan være effektiv, må han/hun fremføre et performativ, der er så overbevisende, at aktørens "nye" fortælling anerkendes som den rette. Antropologen Clifford Geertz (1926-2006) beskriver det således i sin artikel "Deep Play: Notes on a Balinese Cockfight", ${ }^{16}$ at det sociale performativ fortæller historien om os selv - for os selv. Målet for et socialt performativ er meget lig ambitionerne for religiøse ritualer, der står og falder med deres evne til at producere en identifikation og kulturel udbredelse. Hensigten er således igennem et vedkommende og bevægende performativ at skabe følelsesmæssige bånd mellem en situation, en kulturel aktør og et publikum. Udfordringen for den kulturelle aktør er at overvinde den fragmentering, der $i$ et samfund kan ligge mellem a) situationen for det sociale performativ - begivenheden og bagtæppet, den fælles erindring og historie b) aktørens reelle hensigter eller mangel på samme og den sammenhæng han optræder i mise-en-scène, ${ }^{17}$ og c) publikums identifikation eller forkastelse af aktørens tydning af en begivenhed og budskab. Da publikummets forståelse og dom over aktørens optræden ikke er en proces, hvor et positivt resultat forekommer automatisk, står og falder det sociale performativ for aktøren $i$ en overvindelse af fragmentationen mellem situation, aktør og publikum (Alexander 2006, 76), altså et performativ med det rette flow som Victor Turner omtaler en vellykket performance. ${ }^{18}$

\section{Frejdigt Mod i Jesu Navn! Prædiken paa Palmesøndag 1864}

Genstanden for undersøgelsen er som sagt Ludvig Helvegs prædiken Frejdigt Mod i Jesu Navn! Palmesøndag 1864. Denne prædiken er interessant, fordi den viser hvorledes den sociale aktør og meningsdan-

16. Clifford Geertz, "Deep Play: Notes on a Balinese Cockfight", The Interpretation of Cultures: Selected Essays (New York: Basic Books Inc. Publishers 1973), 448. 17. "In theatrical terms as mise-en-scène, which translate literally as "putting into the scene" defining mise-en-scène as the confrontation of text and performance." J.C. Alexander, "Cultural Pragmatics: social performance between ritual and strategy", Social Performance: Cultural Pragmatics and Ritual, 29-90 (63).

18. Victor Turner, Liminal to Liminoid, in Play, Flow, and Ritual: An Essay in Comparative Symbology, The Rice University Studies Volume 6:3, Summer (Houston: Rice University 1974), 87-90. 
ner Helveg fra prædikestolen agerer på vegne af den danske nation i en konflikt og krisesituation. Om Helvegs performative formåen Palmesøndag 1864 kan der kun gisnes om, da der ingen øjenvidneskildringer er at finde. Hvad vi har, er den trykte tekst fra 1864, men der forligger en reel mulighed for, at han formåede at overvinde fragmentationen og skabe et flow mellem situation, aktør og publikum, da prædikenen senere blev trykt $\mathrm{i}$ et større oplag til et velgørende formål. ${ }^{19}$

Det syntes tydeligt i denne prædiken, i hvor høj grad dansk teologi, kristendom og kirke indvirkede på konstruktion af en fælles dansk identitet udtrykt igennem konstruerede narrativer og nationale symboler. Ludvig Helveg (1818-1883) var grundtvigiansk præst og kirkehistoriker. ${ }^{20}$ Da han blev cand. theol. i 1840, havde han tænkt sig at søge universitetsvejen, men måtte sande som andre erklærede grundtvigianske teologer, at den akademiske vej ville blive vanskeliggjort af deres teologiske valg. ${ }^{21}$ I 1857 tiltrådte han embedet som residerende Kapellan ved Odense Domkirke og præst ved Hospitalskirken. ${ }^{22} \mathrm{~N}$. Clausen-Bagge skriver i sin bog med skildringer af tyve grundtvigianske profiler, at Helveg havde succes i sit arbejde med menighederne: "Der kom mange i begge Kirkerne; men størst betydning fik nok Gudstjenesterne i Hospitalskirken, hvor der samledes en Frimenighed" (Clausen-Bagge 1942, 48). Prædiken fra Palmesøndag den 20. marts 1864 kan derfor meget vel være blevet brugt både i Domkirken $^{23}$ og Hospitalskirken i Odense. Fyn og Odense må have haft krigen tæt inde på livet, da øen fungerede både som opmarchområde og som den danske hærs bagland. Her lå hæren i beredskab klar til de kommende operationer, og her fandt man depoter af enhver art, indeholdende alt fra heste til udrustningen af den menige soldat $\mathrm{i}$ kavaleriet, infanteriet og artilleriet. Det myldrede med soldater overalt. Efter voldsomme krigshandlinger kunne fynboerne iagttage syge sårede blive bragt til øens mange sygehuse og lazaretter. Feltpræsten

19. Indtægten fra salget af Helvegs prædiken blev anvendt til anskaffelse af sanghæfter for hæren. Til soldaten i den danske hær ved fronten blev der distribueret skillingshæfter (tryksager i lille format der kunne ligge i en uniformslomme) til fordeling blandt bataljonerne, med sange af åndeligt, nationalpatriotisk eller humoristisk indhold.

20. Det skal tilføjes at Helvegs broder var præsten, forfatteren og højskoleforstanderen Fr. Helveg (1816-1901).

21. N. Clausen-Bagge, Grundtvigske Banebrydere - 20 korte skildringer (Odense: Andelstrykkeriet i Odense 1942), 47-48.

22. Den eneste stilling han bestred som præst fra 1857 til kort før sin død i 1883. Ludvig Nicolaus Helveg fik med tiden sin akademiske æres oprejsning og modtog både graden som Dr. Phil. og Æresdoktor theol. (1879) ved Københavns Universitet (Clausen-Bagge 1942, 47).

23. Skt. Knuds Kirke. 
Peter Rørdam (1806-1883), der opholdt sig i Fredericia små 55 kilometer fra Odense, beskriver situationen netop denne Palmesøndag i et brev mandag den 21 marts til sin kone:

Fra igaarmorges, Palmesøndag, har de beskudt Byen fra 4 kanter; hvor man gaaer og staaer, suser Kuglerne over Hovedet og om Ørene; Det ene Huus brænder efter det andet. Jeg forrettede Jordpaakastelse Kl. 8 over 3 Døde, men fik talt yndigt med den store Forsamling om Omvendelse og tro; "Thi ved Omvendelse og Rolighed skal I frelses". ${ }^{24}$

\section{Kulturel aktør}

Det er med denne situation som bagtæppe og mise-en-scène, at Helveg stiller sig på prædikestolen i Odense og prædiker over bibelteksten om Kristus indtog i Jerusalem fra Matt. 21,1-10. Prædikenen syntes skrevet som et moralsk drama, hvor Helveg ikke kun søger at give sin menighed en fællestolkning af krigen, men også en moralsk opsang til den enkelte i forsamlingen om mod og kristelighed i nødens stund. ${ }^{25}$ Et sted siger han således:

Men at Christi Mand ikke er en Feighedens og Blødagtighedens Mand, der ræd viger tilbage for Faren, det kunne vi see, naar vi efter Dagsevangeliets Anviisning, peger hen paa den Davids Søn som han holder sit indtog i denne Morderstad. ${ }^{26}$

Den højstemte tone i Helvegs prædiken står, i nogen kontrast til krigens realiteter og begivenhederne ved fronten i Fredericia, jævnfør feltpræsten Peter Rørdams nøgterne linjer om omvendelse og rolighed. Betydningen af truslen mod nationen og de sønderskudte soldater fra fronten behandles og beskrives i Helvegs prædiken i et kristent lys:

"Ingen har større kjærlighed end den, der sætter Livet til for sine Venner". Disse Jesu Ord til sine Disciple, som vi læse Joh. 15.13, naar vi vel særlig mindes i denne Tid, hvor hver Dag bringer os Budskab om de mange Offere, den blodige Kamp på Valen kræver, og vi skulle ogsaa lægge al Vægt paa hine Jesu Ord, naar vi lære at se Kampfærden og den

24. Peter Rørdam, Blade af hans Levnedsbog og Brevvexling, red. H.F. Rørdam (København: Karl Schønbergs Forlag 1894), 195.

25. Bernhard Giesen, "Performing the Sacred: a Durkheimian perspective on the performative turn in the social sciences", Social Performance: Cultural Pragmatics and Ritual, 325-367 (327).

26. Ludvig Helveg, Frejdigt Mod i Jesu Navn! Prediken paa Palmesøndag 1864 (Odense: Fyens Stiftsbogtrykkeri 1864), 2. 
blodige Død på Valen i dens ægte menneskelige og dermed ogsaa dens rette christelige Lys (Helveg 1864, 2).

Når Helveg omtaler kampfærden på valen i samme sætning som Jesu ord fra Joh. 15,13, indsætter han sine egne og menighedens oplevelser af tab og ødelæggelse i en fortælling om den "gode" død i det rette kristelige lys. Som mennesker og individer er der specielle øjeblikke i vores liv, hvor vi reflekterer over vores egen særegne identitet og de sammenhænge, som udgør rammen om vores liv her på jorden som mennesker. Vi må uvægerligt henvise til den liminale horisont i vores eksistens - fødslen og døden som er fælles for os alle. Den fundamentale vished om, at vi alle er født og at vi alle skal herfra, står i skarp kontrast til den manglende viden og tilgængelighed om netop disse begivenheder i vores liv. Det er os umuligt at beskrive disse øjeblikke, men vi kender til dem og kan observere den "hårde" fødsel eller "den gode" død hos andre mennesker omkring os; det er kun med reference til andres fødsel og død at det er muligt for os at forestille sig vores eget endeligt. I denne henseende går den kollektive identitets forestilling om døden forud for den enkeltes bevidsthed om egen mortalitet. ${ }^{27} \mathrm{I}$ kraft af menneskets evne til refleksionen over egen mortalitet konstrueres en fælles identitet; netop fordi vi alle skal herfra, kædes vi sammen som mennesker. Men sommertider indvirker eksterne kræfter pludseligt og voldsomt i vores personlige sfære, med handlinger der truer vores fælles identitet, eksistens og erindringer og som minder os om vores mortalitet, såsom de ulykkelige hændelser omkring den 21 marts 1864. Vi generindrer disse voldsomme oplevelser igen og igen som traumatiske minder i vores diskussioner med vores medmennesker, minderne refererer til vores mortalitet, ikke kun som en mulighed der kunne have overgået os, men som en reel oplevelse (Giesen 2004, 45). Som Helveg selv udtrykker det i sin prædiken:

For Dyret er Livet det højeste, og det giver Alting hen, for blot at kunne bjerge sit Liv, men hvad skulle vi kalde det Menneske, der handler på denne Viis, der gjerne vil hengive sine Venner og Frænder, Hustru og Børn, sit Fædreland, sin Ære, naar han blot kan bjerge sit usle Liv? Det er dog derpaa den menneskelig Højhed skal findes, at der er noget vi elsker højere end Livet, at der er os noget saa kjært, saa dyerbart, så helligt, at vi ville døe på det og døe for det! Det var det, vore hedenske Forfædre saae, og derfor priste de Heltedøden på Valen, som et talende Vidnesbyrd om, at Menneskelivet har en evig Indvielse, at der er noget i os, som er stærkere end Døden, og som giver Mod til selv at gaae Døden under Øinene (Helveg 1864, 4).

27. Bernhard Giesen, Triumph and Trauma, The Yale Cultural Series (Boulder: Paradigm Publishers 2004), 8. 
Krigen som Helveg kommenterer på ligger i periferien af den sociale orden. Den er en udfordring i forhold til det ikke alment kendte, en krisetilstand, der ikke bare kan forklares i gængse termer, men kræver en ekstraordinær fortælling (Giesen 2004, 15). Helveg påpeger i sin sammenligning af dyret og mennesket, at netop det der skiller os fra dyret og løfter os over det, er den frie vilje. Igennem denne vilje kan menigheden, soldaten og læseren af prædiken, drage de korrekte moralske valg og opnå et liv i det rette kristelige lys. For i disse krisesituationen er der brug for de rette moralske helte - ikke bare naboens Hans, men nogle der vil overvinde døden, være undtagelsen fra reglen, stå udenfor fælleskabet og dog repræsentere det i nødens stund på valen. Helte som disse kan tolkes som konstruktioner skabt af sociale aktører som Helveg, de er kollektive projektioner af ophøjet subjektivitet, den triumferende kropsliggørelse af den kollektive identitet. Heltene ved fronten der giver sig hen for frænder og familie, er skikkelser der symboliserer fællesskabets bånd til det transcendente, muligheden for individer til at løfte sig over det mondæne og med Helvegs egne ord være "det talende vidnesbyrd om, at menneskelivet har en evig indvielse, at der er noget i os, som er stærkere end døde" (Helveg 1864, 4). I konstruktionen af helten skabes der sociale bånd, der transcenderer rammerne for det individuelle liv, for gruppen, menigheden, nationen. På vegne af fællesskabet trodser helten smerte og lader hånt om døden på slagmarken; han/hun opnår en udødelighed der ellers kun hører Gud/guderne til. Forlægget og modellen for selvopofrelse på vegne af fælleskabet er par excellence at finde i beretningerne om de kristne martyrer, der gav sig hen for troen og fællesskabet, og i døden søgte en efterfølgelse af Kristus på korset. Gennem helten overvinder fællesskabet ikke bare profane bånd og forpligtelser, men også truslen om død og ødelæggelse og der skabes et håb om frelse.

Også økonomen og sociologen Max Weber (1864-1920) diskuterer overskridelsen af det profane og forbindelsen til transcendente i fællesskabets helte. I sin tekst "Det karismatiske herredømme og dets omdannelse", ${ }^{28}$ er det karismatiske det, der rækker ud over normalen, det der konstitueres af fællesskabets tro på heltens ekstraordinære kvaliteter. I en webersk forstand kropsliggør helten det karismatiske, han sammensmelter det hellige med det profane og bliver et bindeled til det guddommelige (Giesen 2004, 18). Helten, der giver sig selv hen i krigen, bliver en idealskikkelse, der via sin gerning løfter de ordinære dødelige ud af det daglige liv og krisen (Giesen 2006, 334). De mytiske sagn, de bibelske historier og de religiøse fortællinger genfortælles

28. Max Weber, "Det karismatiske herredømme og dets omdannelse", Max Weber - Udvalgte Tekster bd. 2, red. Andersen, Bruun \& Kaspersen (København: Hans Reitzels Forlag 2003), 115-188. 
ikke kun igen og igen, de genopføres af kulturelle aktører i sociale performativer for at give en krise sin "rette" betydning. Heltenes (og skurkenes) fortællinger er selve rammen og rygraden i samfundets historie om sig selv - ingen fællesskaber kan fuldstændigt udelukke disse konstruerede historier, der har til formål at relatere fortiden og den fælles erindring med nutiden, den profane verden med det hellige, det synlige med det usynlige. ${ }^{29}$

\section{Der er et yndigt land}

Helvegs brug af de hedenske, men ædle forfædre, inkorporerer menigheden i Odense, den danske soldat og læseren af prædiken, både temporalt og geografisk i den skandinaviske nationale selvbiografi, i det "store narrativ" - om Os. Således kan man sige, at oplevelsen af det nutidige afhænger af en viden om fortiden, samtidig med at forståelsen af fortiden legitimerer en nutidig social orden. Individer og grupper fra en fjern fortid bliver gjort til en forlængelse af os, "vore" forfædre, uden at der skeles til andre historiske muligheder eller sandheder. Kernen er historien om os, en samlende, homogen fortælling, hvor danskere og Danmark er et trans-historisk fænomen. Denne historie om "os" og om "vore" forfædre, forudsætter en illusion af udbrudte nationale slægtsled fra de modige danske vikinger og frem til "os" og "vort" fædrelands frelse. ${ }^{30}$

Saaledes seet er der dyb Sandhed i vore hedenske Forfædres Betragtning af Kamplivet og Kampmodet, og det Valhalla, hvorom de drømte, det skal vi bygge, vi for hvem de have stridt og lidt, bygge derved at vi hædrer deres Minde, at det kan leve fra Slægt til Slægt, og Børn og Børnebørn kunne fortælle om dem, der havde blødt for vort Fædreslands Frelse (Helveg 1864, 5).

Ideen om en national trans-historisk og transcendental skæbne opmuntrer os i krisetider til at forestille os nationen som et rent, ædelt og udvalgt broderskab, ${ }^{31}$ ydermere tilskynder denne tanke os til at adlyde nationens kald til at ofre sig i den gode sags tjeneste. ${ }^{32}$ Når

29. Joseph Campbell, The Hero With a Thousand Faces Bollingen Series XVII (Princeton, NJ: Princeton University Press 1972).

30. Fredrik Svanberg, Decolonizing the Viking Age 1, Acta Archaeologica Lundensia Series 8 No. 43 (Stockholm: Almqvist \& Wiksell International 2003), 99.

31. Kai Erikson, "Notes on Trauma and Community", Trauma Exploration in Memory, red. Cathy Caruth (Baltimore, MA: The Johns Hopkins University Press 1995), 183-199 (186).

32. Anthony D. Smith, Chosen Peoples (Oxford: Oxford University Press 2003), 20. 
Helveg i en kreative dialog med fortiden bruger af det hedengangne nationale arvegods, er det på ingen måde særegent for ham, men findes ligeledes hos andre kulturelle personligheder og aktører i hans samtid. ${ }^{33}$ Narrativet om de modige "daner", der blødte for landet, kan ses som en moralsk opbygning af en fælles samvittighed, et nationalt projekt, der presser en homogenitet nedover en fjern fortid, for at kunne mobilisere befolkningen i en nutidig krisetid. Når Helveg i sin prædiken italesætter de danske soldaters død på valen, som værende lig de ædle vikinger, da forudsættes der en fælles viden om Danmark $i$ en mytisk storhed, fra dengang da "danerne" alle var "ædle" krigere, der frelste nationen og vandt hæder. Den 2. Slesvigske Krig skabte ud af tragedien et lille land med en sprogligt, religiøs og kulturelt homogen befolkningssammensætning. I sin reducerede skikkelse var folk, nation og stat nu næsten fuldstændigt sammenfaldende.

33. I denne sammenhæng kan nævnes N.F.S. Grundtvig (1783-1872), B.S. Ingeman (1789-1862) og Adam Oehlenschläger og deres arbejde med den danske historie i en form for oldnordisk patriotisme. Flemming Lundgreen-Nielsen, "Oldnordisk patriotisme”, Dansk Identitetshistorie: Folkets Danmark 1848-1940 bd. 3, red. Old Feldbæk (København: C.A. Reitzels Forlag 1992), 15-18. 